\title{
EVALUATION OF WATER QUALITY AND TROPHIC CONDITION OF YUVACIK (KOCAELI-TURKEY) DRINKING WATER DAM RESERVOIR
}

\author{
*Erkan KALIPCI, Department of Geomatics Engineering, Giresun University, Turkey, erkan.kalipci@giresun.edu.tr \\ (iD https://orcid.org/0000-0002-1908-5468) \\ Selçuk VAROL, Department of Environmental Engineering, , Nevsehir Hacı Bektas Veli University, Turkey, \\ selcukvarol@hotmail.com.tr \\ (iD https://orcid.org/0000-0002-0728-1162)
}

Hüseyin CÜCE, Department of Geomatics Engineering, Giresun University, Turkey, huseyin.cuce@giresun.edu.tr

(iD) https://orcid.org/0000-0002-3590-681X)

Received: 16.08.2020, Accepted: 03.11.2020

Research Article

*Corresponding author

DOI: $10.22531 /$ muglajsci.781242

\section{Abstract}

This study was conducted in order to examine some physico-chemical properties and determine the trophic status of Yuvacı Dam Lake, which is located within the provincial borders of Kocaeli, to reveal the surface water quality and pollution problems. Raw water samples were taken from 5 different stations at different depths for two periods (September 2016 and May 2017). As a result of the research, it was found that the average values of water quality parameters of Yuvacık Dam Lake are in the range of water quality class I (high quality, very good) - II (slightly polluted, good) according to the quality criteria. According to the eutrophication criteria, the trophic level of the lake was mesotrophic in terms of total nitrogen (TN) and total phosphorus (TP) concentration, oligotrophic in terms of chlorophyll-a, and periodically mesotrophic in terms of light transmittance. The mean Trophic State Index (TSI) value was calculated as 44.1 and it was determined that the trophic level of the lake was mesotrophic.

Keywords: Yuvacık dam, Water quality, Trophic level, Kocaeli.

\section{YUVACIK (KOCAELİ-TÜRKIYE) İÇME SUYU BARAJ REZERVUARI SU KALİTESİ VE TROFİK DURUMUNUN DEĞERLENDİRİLMESİ}

\section{Özet}

Bu çalışma, Kocaeli il sınırları içinde yer alan Yuvacık Baraj Gölü'nün yüzey suyu kalitesini ve kirlilik problemlerini ortaya koymak üzere bazı fiziko-kimyasal özelliklerini incelemek ve trofik durumunun belirlenmesi amacıyla yapılmıștır. 5 farklı istasyondan farklı derinliklerde iki dönem (Eylül 2016 ve Mayıs 2017) hamsu numuneleri alınmıştır. Araştırma sonucunda Yuvacık Baraj Gölü'nün su kalite parametrelerinin ortalama değerlerinin kalite kriterlerine göre su kalite sınıfı I (yüksek kalite, çok iyi)- II (az kirlenmiş, iyi) aralığında olduğu tespit edilmiştir. Ötrofikasyon kriterlerine göre gölün trofik düzeyinin toplam azot (TN) ve toplam fosfor (TP) konsantrasyonu açısından mezotrofik, klorofil-a açısından oligotrofik, ışık geçirgenliği açısından ise dönemsel olarak mezotrofik seviyede olduğunu göstermiştir. Ortalama Trofik durum indeks (TSI) değeri 44.1 olarak hesaplanmış ve gölün trofik seviyesinin mezotrofik olduğu belirlenmiştir.

Anahtar Kelimeler: Yuvacık barajı, Su kalitesi, Trofik seviye, Kocaeli.

Cite

Kalıpcı, E., Varol, S. and Cüce, H. (2020). "Evaluation of water quality and trophic condition of Yuvacık (Kocaeli) drinking water dam reservoir", Mugla Journal of Science and Technology, 6(2), 128-139.

\section{Introduction}

In order to ensure the continuity of the ecological balance, the quality of water is as important as the presence of water [1]. The rapid increase in the world population, urbanization, industrialization, and the unconscious excessive use of pesticides and fertilizers in agricultural areas have disrupted the quality of water resources and water resources have turned into recipient environments where wastes are discharged
[2]. In Turkey, it has been determined by the Provincial Directorates of Environment and Urbanization that the primary environmental problem of cities is water pollution and when the priority environmental problems are compared over the years, there has been an increase in water pollution-related problems in the last five years. It has been determined that the possible causes of contamination of surface waters are respectively domestic wastewater, agricultural activities, domestic solid wastes, industrial wastes / 
wastewater and maritime activities. Besides; It has been determined that the lack of treatment of domestic wastewater in the city center and settlements in districts is the most important reason for the pollution arising from wastewater, and the absence or insufficient sewerage network follows this [3]. Safe water; It is necessary for the continuity of life, drinking, cooking, cleaning as well as agricultural and gardening needs [4]. In order to ensure the continuity of ecological balance and to benefit from water resources efficiently, water quality should be monitored repeatedly in certain periods, and important factors that affect pollution change should be identified and appropriate precautions should be taken [5-8]. Especially; Point and non-point pollutant sources around dams used as drinking and potable water should be taken under control [9]. In this study, the water quality and trophic status of the Yuvacik Dam reservoir, which supplies the drinking water need of Kocaeli province, was evaluated.

\section{Material and Methods}

\subsection{Definition and Features of the Study Area}

Yuvacık Dam Reservoir, determined as the study area, covers an area of $257.86 \mathrm{~km}^{2}$, which was built to provide drinking water to the province of Kocaeli and its surroundings, and the total feeding area covers a part of Kocaeli, Sakarya and Bursa provinces. Some general information about Yuvacık Reservoir is given in Table 1. [10].

Dam; It is divided into four sub-basins in terms of water management. Three of these basins are Kirazdere, Serindere and Kazandere sub-basins, which have an important share in feeding the reservoir. The map showing the lower basin boundaries of Yuvacık dam is given in Figure 1. Apart from these sub-basins, it is located in a basin surrounding the reservoir, which is defined as an intermediate basin in terms of dam management. Serindere forms the largest sub-basin with a feeding area of $120.53 \mathrm{~km}^{2}$, followed by Kirazdere with $79.54 \mathrm{~km}^{2}$, Kazandere with $23.10 \mathrm{~km}^{2}$ and an intermediate basin with $34.69 \mathrm{~km}^{2}$, respectively $[10,11]$.

Table 1. Some general information about Yuvacık Dam Reservoir [10].

\begin{tabular}{|c|c|}
\hline Dam Reservoir Information & Value \\
\hline Crest Level (m) & 172.5 \\
\hline Thalweg Elevation (m) & 70 \\
\hline Thalwegden Height (m) & 102.5 \\
\hline Height from Foundation (m) & 108.5 \\
\hline Crest Length (m) & 399 \\
\hline Crest Width (m) & 12 \\
\hline Yuvacık Dam Total Drainage Area $\left(\mathrm{km}^{2}\right)$ & 257.86 \\
\hline Kirazdere Drainage Area $\left(\mathrm{km}^{2}\right)$ & 79.54 \\
\hline Kazandere Drainage Area $\left(\mathrm{km}^{2}\right)$ & 23.10 \\
\hline Serindere Drainage Area $\left(\mathrm{km}^{2}\right)$ & 120.53 \\
\hline Interim Basin $\left(\mathrm{km}^{2}\right)$ & 34.69 \\
\hline Minimum water level (m) & 112.50 \\
\hline Normal water level (m) & 169.30 \\
\hline Maximum water level (m) & 169.68 \\
\hline Dam Reservoir Surface Area at Minimum Water Level ( $\left.\mathbf{m}^{2}\right)$ & 346.656 \\
\hline Dam Reservoir Surface Area at Normal Water Level $\left(\mathrm{m}^{2}\right)$ & 1.723 .886 \\
\hline Dam Reservoir Surface Area at Maximum Water Level $\left(\mathrm{m}^{2}\right)$ & 1.736 .685 \\
\hline Dam Reservoir Useful Volume at Minimum Water Level $\left(\mathrm{m}^{3}\right)$ & 0 \\
\hline Reservoir Useful Volume at Normal Water Level (m³) & 51.126 .056 \\
\hline Dam Reservoir Useful Volume at Maximum Water Level $\left(\mathrm{m}^{3}\right)$ & 51.795 .142 \\
\hline Dead Volume $\left(\mathrm{m}^{3}\right)$ & 4.900 .000 \\
\hline Annual Regulated Water (Million $\mathbf{m}^{3}$ / year) & 142 \\
\hline Annual Flow (Million $\mathrm{m}^{3}$ / year) & 220.8 \\
\hline Regulation Rate (\%) & 64.3 \\
\hline Catastrophes Sepate Peak $\left(\mathrm{m}^{3} / \mathrm{h}\right)$ & 1593 \\
\hline
\end{tabular}




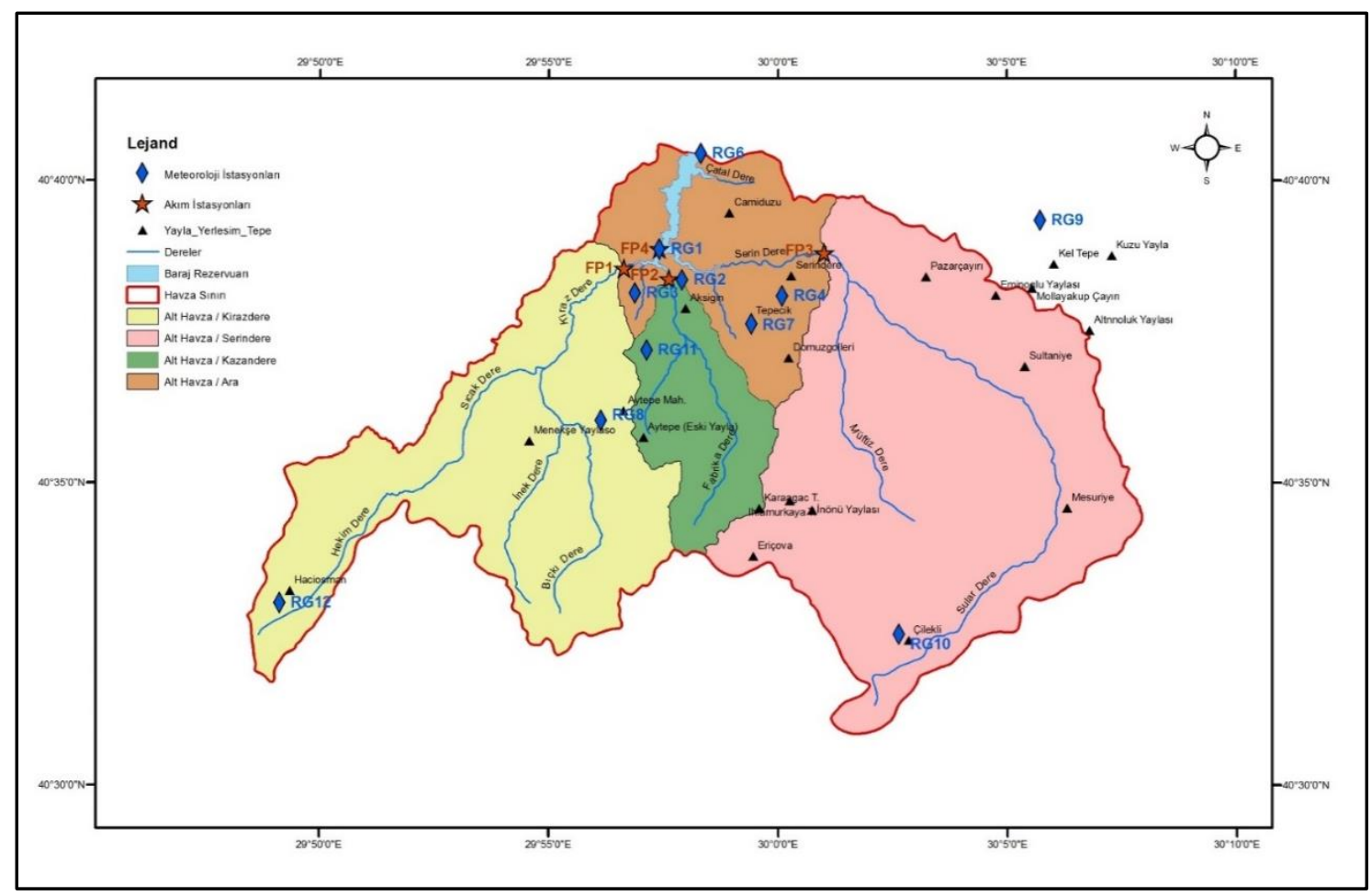

Figure 1. The map showing the lower basin boundaries of the Yuvacık Dam [11].

The minimum water level of the dam is $112.50 \mathrm{~m}$ dsg, and the maximum water level is $169.68 \mathrm{~m}$ dsg. The dam lake surface area at minimum water level is $346,656 \mathrm{~m}^{2}$, and the surface area at maximum water level is $1,736,685 \mathrm{~m}^{2}$. The useful volume of the reservoir is approximately 51 million $\mathrm{m}^{3}$, and its dead volume is 4.9 million $\mathrm{m}^{3}$. The annual flow rate of the dam is 220.8 million $\mathrm{m}^{3}$ / year. Yuvacık dam has an annual capacity of 142 million $\mathrm{m}^{3}$ of treated water, which corresponds to a regulation rate of $64.3 \%$ [10].

The dam lake is used for raw water storage, flood and overflow prevention as well as water management during drought periods. After the drought in 2006, the Sapanca Lake promotion system was implemented by Kocaeli Metropolitan Municipality Izmit Water Sewerage Administration (ISU) General Directorate to provide raw water support from Sapanca Lake to Yuvacık Dam. In addition, approximately 80 wells were drilled in 2014 to meet Izmit's water need during the drought period and the groundwater taken from the alluvial aquifer was transferred to the treatment plant [12].

There are many large and small streams in the Yuvacik dam basin. The largest streams are Kirazdere, Serindere and Kazandere creeks, which have an important share in feeding the dam lake. The stream in the Serindere Yuvacık basin is the stream with the highest flow, followed by Kirazdere and Kazandere, respectively. When the daily stream flow data of 2006-2015 are evaluated statistically, Serindere displays an average flow rate of $2.09( \pm 2.51) \mathrm{m}^{3} / \mathrm{sec}$, Kirazdere $1.35( \pm$ 1.79) $\mathrm{m}^{3} / \mathrm{sec}$ and Kazandere $0.58( \pm 0.76) \mathrm{m}^{3} / \mathrm{sec}$ [13].

Yuvacık dam is divided into 4 sub-basins in terms of water management. These are Serindere, Kirazdere, Kazandere and Interim sub-basins. Daily flow data are measured regularly in sub-basins outside the basin defined as intermediate basin. When the current longterm flow data are examined (2006-2015), it has been observed that there is an average of $28 \%$ difference between the total flow entering the dam reservoir and the total flow originating from Serindere, Kirazdere and Kazandere. This situation shows that approximately $28 \%$ of the flows in the basin cannot be measured. The flows that cannot be measured belong to the sub-basin defined as the intermediate basin. Average $36 \%$ of the flows entering the Yuvaclk Basin originate from Serindere, 30\% from Interim Basin, 24\% from Kirazdere and $10 \%$ from Kazandere. The total annual flows entering the Yuvacık Reservoir from different basins or sources are given in Table 2 and the proportional distribution of the average flows entering the Yuvacik Reservoir is given in Figure 2 [13]. 
Table 2. Total annual flows entering Yuvacık Reservoir from different basins or sources [13].

\begin{tabular}{cccccc}
\hline Year & $\begin{array}{c}\text { Kirazdere } \\
\left(\mathbf{~ m}^{\mathbf{3}} \mathbf{)}\right.\end{array}$ & $\begin{array}{c}\text { Serindere } \\
\left(\mathbf{~ m}^{\mathbf{3}} \mathbf{)}\right.\end{array}$ & $\begin{array}{c}\text { Kazandere } \\
\left(\mathbf{~ m}^{\mathbf{3}} \mathbf{)}\right.\end{array}$ & $\begin{array}{c}\text { Interim Basin } \\
\left(\mathbf{~ m}^{\mathbf{3}} \mathbf{)}\right.\end{array}$ & $\begin{array}{c}\text { Dam total } \\
\text { input flows }\left(\mathbf{~ m}^{\mathbf{3}} \mathbf{)}\right.\end{array}$ \\
\hline $\mathbf{2 0 0 8}$ & 63.061 .261 & 47.571 .805 & 15.645 .445 & 36.342 .543 & 162.621 .054 \\
$\mathbf{2 0 0 9}$ & 29.270 .625 & 51.782 .602 & 15.752 .274 & 46.201 .559 & 143.007 .060 \\
$\mathbf{2 0 1 0}$ & 35.300 .701 & 46.528 .119 & 17.394 .220 & 53.926 .038 & 153.149 .077 \\
$\mathbf{2 0 1 1}$ & 39.457 .228 & 65.991 .843 & 23.118 .942 & 62.798 .404 & 191.366 .416 \\
$\mathbf{2 0 1 2}$ & 50.979 .931 & 76.519 .607 & 22.029 .743 & 65.072 .758 & 214.602 .038 \\
$\mathbf{2 0 1 3}$ & 43.300 .026 & 59.663 .871 & 14.722 .696 & 67.865 .849 & 185.552 .443 \\
$\mathbf{2 0 1 4}$ & 37.900 .876 & 87.423 .056 & 18.608 .590 & 58.508 .460 & 202.440 .981 \\
$\mathbf{2 0 1 5}$ & 24.148 .045 & 43.162 .347 & 10.124 .709 & 34.079 .905 & 111.515 .006 \\
Average & 40.427 .336 & 59.830 .406 & 17.174 .577 & 53.099 .439 & 170.531 .759 \\
\hline
\end{tabular}

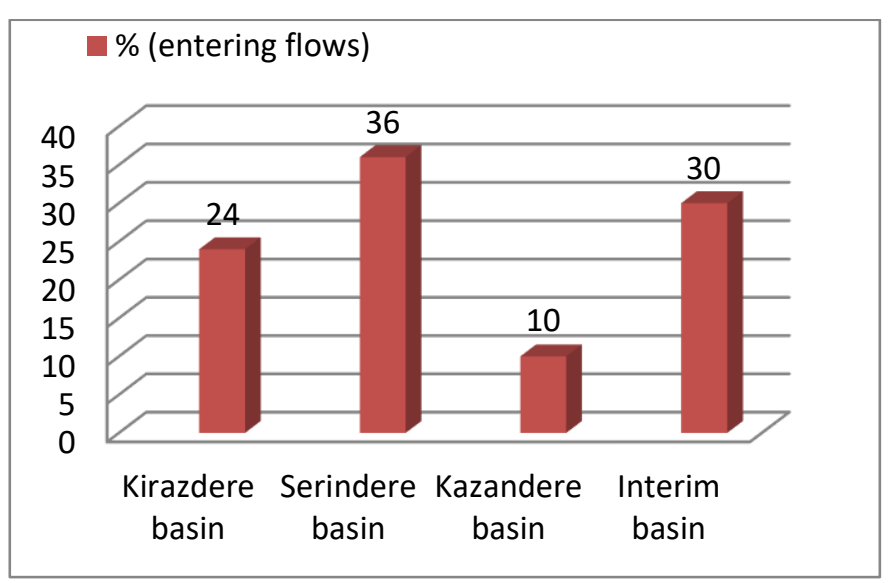

Figure 2. Proportional distribution of flows entering the Yuvacık Reservoir (average values) [13].

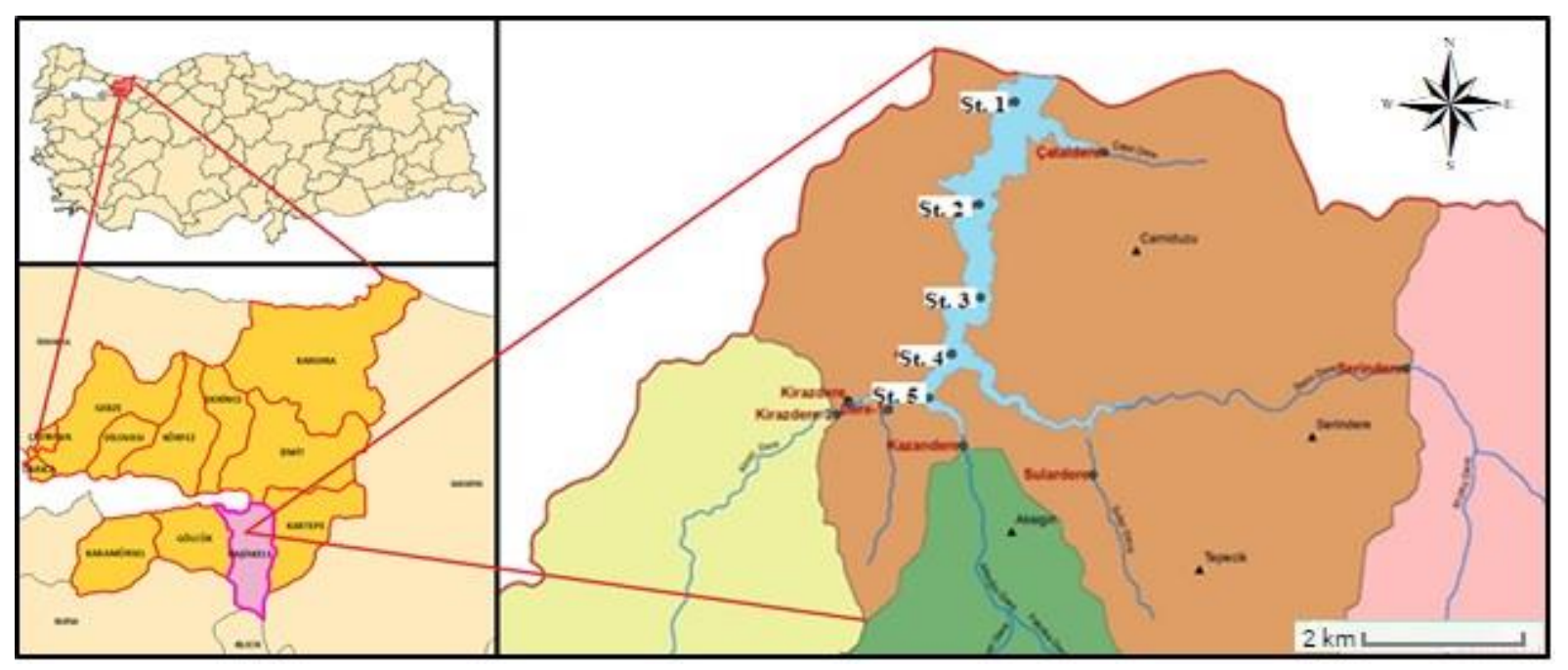

Figure 3. The locations of surface water measurement stations in the Yuvacık Dam basin.

\subsection{Sampling Stations and Analysis Methods}

Within the scope of the study, 5 different measurement stations were determined on the Yuvacık Reservoir in September 2016 and May 2017 and the locations of the measurement points are shown in Figure 3. Sampling station 1 is located close to the water intake structure of the treatment plant. Although there is a variation in the measurement depth periodically, water samples were taken from $5 \mathrm{~m}, 10 \mathrm{~m}, 25 \mathrm{~m}, 30 \mathrm{~m}$ and $50 \mathrm{~m}$ depths 
respectively at this point. Station 1 is the station with the deepest sampling depth. Of the other sampling points, station number 2 is located near the middle of the dam reservoir, station number 3 is towards the south end of the dam reservoir, station number 4 is at the junction point of the Serindere dam reservoir, and station number 5 is near the Kirazdere-Kazandere junction point. Samples; It was taken in accordance with the "Water Pollution Control Regulation, Sampling and Analysis Methods Rescript" and it was stored in glass bottles at a temperature of $+4^{\circ} \mathrm{C}$ and transported to the laboratory environment. Analyzes were made in the laboratory of ISU General Directorate Laboratory Branch Directorate, which has an accreditation certificate. The methods used in the analysis are shown in Table 3. The Surface Water Quality Regulation (SWQR) published in the Official Gazette dated 30/11/2012 and numbered 28483 (Amended: RG-10/8 / 2016-29797; Annex 5 Table 2 According to Classes of General Chemical and Physicochemical Parameters of Inland Surface Water Resources Quality Criteria and Annex 6 Table 9: Lake, Pond and Dam Lakes Eutrophication Criteria). Table $4 \mathrm{a}$ and Table $4 \mathrm{~b}$ shows the SWQR water quality classifications and trophic classes, respectively. The results of the analysis were also evaluated by considering the limit values of the trophic classification system based on SWQR and Carlson model. Descriptions of trophic states are made from examination of several diverse criteria, such as concentration of nutrients, productivity, faunal and floral quantity and quality, oxygen availability, and lake morphometry. The trophic state index (TSI), developed by Carlson R., is used to measure water quality of a lake or reservoir. It has four general states: oligotrophic, mesotrophic, eutrophic, or hypereutrophic. TSI provides a simple singular scheme for classifying the eutrophication condition of a water body in a way that could be easily understood by the relevant stakeholders. In theory the maximum limit of TSIs value is indefinite, but in practice, the scale of the index is from 0 to 100 , and corresponds generally to transparency extremes $(0.06 \mathrm{~m}$ to $64 \mathrm{~m})$ observed in nature [14]. Each 10 units within this system represents a half decrease in Secchi depth, a one-third increase in chlorophyll concentration and a doubling of total phosphorus amount. Generally the TSIs value below 40 corresponds to oligotrophy, between 40 and 60 - mesotrophy, from 60 to 80 eutrophy, and above 80 - hypertrophy of the lake [1516].

The three trophic state indicators $\left(\mathrm{TSI}_{S D D}, \mathrm{TSI}_{\text {Chla }}\right.$ and

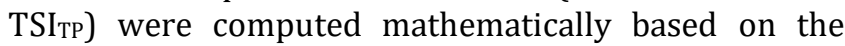
respective equations for the three parameters (Secchi depth, chlorophyll-a and total phosphorus), and the overall Carlson Trophic State Index was calculated by averaging the TSI values obtained from the three trophic state indicators [17]. The equations were as follows:

$$
\begin{aligned}
& T S I(S D D)=10\left(6-\frac{\ln S D D}{\ln 2}\right) \\
& T S I(\text { Chla })=10\left(6-\frac{2.04-0.68 \ln \text { Chla }}{\ln 2}\right. \\
& T S(T P)=10\left(6-\frac{\ln \left(\frac{48}{T P}\right)}{\ln 2}\right.
\end{aligned}
$$

\begin{tabular}{|c|c|c|c|}
\hline Parameter & Unit & Method & Devices and Equipment \\
\hline Temperature & $\left({ }^{\circ} \mathrm{C}\right)$ & SM $2550: B$ & Hq40 Hach Lange Multiparameter \\
\hline Ph (Electrometric Method) & & SM $4500 \mathrm{H}+: \mathrm{B}$ & Hq40 Hach Lange Multiparameter \\
\hline Conductivity & $\mu \mathrm{s} / \mathrm{Cm}$ & SM $2510: B$ & Hq40 Hach Lange Multiparameter \\
\hline Dissolved oxygen & $\mathrm{mg} \mathrm{O}_{2} / \mathrm{L}$ & SM $45000: G$ & Hq40 Hach Lange Multiparameter \\
\hline Chemical oxygen demand & $\mathrm{mg} / \mathrm{L}$ & SM $5220: B$ & Phoro 300 Merc Uv Spektrophotometer \\
\hline Biological oxygen demand & $\mathrm{mg} / \mathrm{L}$ & SM $5210: D$ & BOD bottles, Incubator \\
\hline Ammonium nitrogen & $\mathrm{mg} \mathrm{NH}_{4}{ }^{+}-\mathrm{N} / \mathrm{L}$ & TS EN ISO 14911 & Continuous Flow Analyzer \\
\hline Total kjeldahl nitrogen & $\mathrm{mg} \mathrm{N} / \mathrm{L}$ & SM 4500 NORG :B & Automatic Nitrogen Protein Burning Device \\
\hline Nitrate nitrogen & $\mathrm{mg} / \mathrm{L}$ & TS EN ISO 14911 & Ion Chromatography (IC) \\
\hline Total phosphorus & $\mu \mathrm{g} / \mathrm{L} / \mathrm{L}$ & TS EN ISO 17294-2 & Agilent 7800 ICP MS \\
\hline Orthophosphate phosphorus & $\mathrm{mg} \mathrm{o}-\mathrm{PO}_{4}-\mathrm{P} / \mathrm{L}$ & SM $4500 \mathrm{P}$ ve $\mathrm{E}$ & $\begin{array}{l}\text { Inductively Coupled Plasma Mass } \\
\text { Spectrometer (ICP MS) }\end{array}$ \\
\hline Selenium & $\mu \mathrm{g} / \mathrm{L}$ & TS EN ISO 17294-2 & Agilent 7800 Icp Ms \\
\hline Fluoride & $\mu \mathrm{g} \mathrm{F} / \mathrm{L}$ & TS EN ISO 10304-1 & $\begin{array}{l}\text { Inductively Coupled Plasma Mass } \\
\text { Spectrometer (ICP MS) }\end{array}$ \\
\hline Total nitrogen & $\mu \mathrm{g} / \mathrm{L}$ & ASTM D 5176 & Continuous Flow Analyzer \\
\hline Manganese & $\mathrm{mg} / \mathrm{L}$ & TS EN ISO 17294-2 & Total Organic Carbon Device \\
\hline Chlorophyll-a & $\mu \mathrm{g} / \mathrm{L}$ & TS 9092 ISO 10260 & $\begin{array}{l}\text { Pelkinelmer Optical Emission Spectro. Optima } \\
2100 \mathrm{Dv}\end{array}$ \\
\hline Secchi disk & M & EPA 341-B-97-003 & Inductive Co. Plaz. Atomic Em. (ICP OES) \\
\hline
\end{tabular}

Table 3. Methods used in analysis. 
Table 4a. Water Quality Classifications based on SWQR

\begin{tabular}{|c|c|c|c|c|c|}
\hline \multirow[b]{2}{*}{ Parameter } & & \multicolumn{2}{|c|}{ Water Quality Classes } & \multirow[b]{2}{*}{3} & \multirow[b]{2}{*}{4} \\
\hline & & 1 & 2 & & \\
\hline Temperature & $\left({ }^{\circ} \mathrm{C}\right)$ & $\leq 25$ & $\leq 25$ & $\leq 30$ & $>30$ \\
\hline $\mathrm{Ph}$ & & $6.5-8.5$ & $6.5-8.5$ & $6.0-9.0$ & $<6.0$ or $>9.0$ \\
\hline Conductivity & $\mu \mathrm{s} / \mathrm{Cm}$ & $<400$ & $400-1000$ & $1001-3000$ & $>3000$ \\
\hline Dissolved oxygen & $\mathrm{mg} \mathrm{O}_{2} / \mathrm{L}$ & $>8$ & $6-8$ & $3-6$ & $<3$ \\
\hline Chemical oxygen demand & $\mathrm{mg} / \mathrm{L}$ & $<25$ & $25-50$ & $50-70$ & $>70$ \\
\hline Ammonium nitrogen & $\mathrm{mg} \mathrm{NH}_{4}{ }^{+}-\mathrm{N} / \mathrm{L}$ & $<0.2$ & $0.2-1$ & $1-2$ & $>2$ \\
\hline Total kjeldahl nitrogen & $\mathrm{mg} \mathrm{N} / \mathrm{L}$ & 0.5 & 1.5 & 5 & $>5$ \\
\hline Nitrate nitrogen & $\mathrm{mg} / \mathrm{L}$ & $<5$ & $5-10$ & $10-20$ & $>20$ \\
\hline Total phosphorus & $\mu \mathrm{g} / \mathrm{L} / \mathrm{L}$ & $<0.03$ & $0.03-0.16$ & $0.16-0.65$ & $>0.65$ \\
\hline
\end{tabular}

Table 4b. Trophic Classifications based on SWQR

\begin{tabular}{|c|c|c|c|c|c|}
\hline & & & & & Water Quality Criteria \\
\hline Trophic Classes & $\begin{array}{r}\text { TP } \\
(\mu \mathrm{g} / \mathrm{L})^{-}\end{array}$ & $\begin{array}{r}\text { TN } \\
(\mu \mathrm{g} / \mathrm{L})^{-}\end{array}$ & $\begin{array}{l}\text { Chl-a } \\
(\mu \mathrm{g} / \mathrm{L})\end{array}$ & $\begin{array}{l}\text { Secchi } \\
\text { Depht (m) }\end{array}$ & $\begin{array}{r}\text { DO } \\
(\mathrm{mg} / \mathrm{L})\end{array}$ \\
\hline Oligotrophic & $<10$ & $<350$ & $<3.5$ & $>4$ & $>7$ \\
\hline Mesotrophic & $30-50$ & $650-1000$ & $9-15$ & $2.0-1.5$ & $6-4$ \\
\hline Hypereutrophic & $>100$ & $>1500$ & $>25$ & $<1$ & $<3$ \\
\hline
\end{tabular}

\section{Findings and Discussion}

The chemical analysis results of the surface water samples taken seasonally at different points and depths in the dam reservoir during Dry (September 2016) and Wet (May 2017) periods are given in Table 5 and Table 6.

Reservoir water generally exhibits an alkaline $\mathrm{pH}$ value. $\mathrm{pH}$ must be well known and controllable in order to provide both biological life and chemical balance. $\mathrm{pH}$ is an important criterion of water's tendency to corrosive or precipitate [18]. In the May period ( $\mathrm{pH}$ : $8.1 \pm 0.3)$, compared to the September $(\mathrm{pH}: 7.7 \pm 0.4)$ period, the average $\mathrm{pH}$ value of the water increased by about half a unit. The reservoir water exhibits a slightly alkaline $\mathrm{pH}$ value at depths close to the surface in September and May. It is thought that surface water discharges are effective in alkaline $\mathrm{pH}$ value of water. The electrical conductivity of a water is the sum of the amounts of salts or soluble substances in the water. The electrical conductivity of water depends on both geological factors and external influences. Conductivity; increases in parallel with the increase in temperature and salinity [19]. The EC value of the reservoir water is also moderate and does not show a significant periodic variation (Average EC, May: $234 \pm 7.9 \mu \mathrm{S} / \mathrm{cm}$, September: $236 \pm 7.8 \mu \mathrm{S} / \mathrm{cm}$ ). It is seen that the EC value of the reservoir water is similar to the EC values of the spring water. The reason for the difference in EC values is due to factors such as external water inclusions, precipitation and evaporation [20].

The average temperature of the reservoir raw water measured in September (16.76 $\left.\pm 4.55^{\circ} \mathrm{C}\right)$ was higher than in May $\left(9.8 \pm 2.97^{\circ} \mathrm{C}\right)$. Temperature is the most important parameter to be measured in determining stratification in lakes. Since temperature affects biological and chemical processes in the water source, the concentration of many parameters changes with temperature [20]. It was observed that the temperature increased with the increase in depth in September, and there was no significant change in temperatures depending on the depth in May.

The average dissolved oxygen saturation of the reservoir raw water in September $(84 \pm 23 \%)$ was higher than in May ( $96 \pm 13 \%)$. The amount of dissolved oxygen in water depends on the temperature of the water, air pressure, salt amount and the degree of water pollution [21]. High temperature decreases the solubility of oxygen and decreases the oxygen concentration in water [22]. It is observed that the dissolved oxygen concentration is higher in the May period due to the lower water temperatures in May compared to September. The lowest dissolved oxygen saturation was measured at the midpoint of the dam reservoir (station No 2) at $30 \mathrm{~m}$ depth (42.7\%) and at $50 \mathrm{~m}$ depth $(46.9 \%)$ near the water intake structure 
(Station No 1). The differentiation observed in basic water parameters depending on depth in September period is not observed in May period. Dissolved Oxygen (DO) saturation measured at the deepest points of the reservoir in May was $102 \%$ at the 1 st station $(50 \mathrm{~m})$, $108 \%$ at the 2 nd station $(21 \mathrm{~m})$, and $106 \%$ at the 3 rd station $(25 \mathrm{~m})$. All these data show that the water column in the reservoir was mixed well in the May period. Depending on the temperature changes in a water body, water bodies of different densities are formed in the region. Due to the lower density of the warmer water, it is ranked depending on its temperature by placing it above the water with higher density. This situation causes thermal stratification, which is one of the important parameters affecting the water quality in lakes [22]. Accordingly, it is thought that the stratification caused by the temperature difference in the reservoir in September caused the difference in water parameters.

Yuvacik dam raw water, considering the water quality classes shown in Table 4a; It shows Class I (very good) water quality in terms of $\mathrm{pH}, \mathrm{EC}$, chemical oxygen demand, biological oxygen demand, ammonium nitrogen, nitrate nitrogen, ortho phosphate phosphorus, manganese and selenium parameters. In September 2016, the dissolved oxygen parameter showed Class I (very good) water quality at many points, but the 1 st point was at $25 \mathrm{~m}(7.19 \mathrm{mg} / \mathrm{L})$, the 1 st point at $50 \mathrm{~m}$ (4.69 mg / L). ) and 2. Point $30 \mathrm{~m} \mathrm{(3.27} \mathrm{mg} \mathrm{/} \mathrm{L)} \mathrm{II.} \mathrm{class}$ (good) water quality feature. In May 2017, the dissolved oxygen parameter showed Class I (very good) water quality at many points, but the 1 st point was at $10 \mathrm{~m}$ (7.96 $\mathrm{mg} / \mathrm{L}$ ) and the 3rd point was at $5 \mathrm{~m}(7.34 \mathrm{mg} / \mathrm{L})$. II. class (good) water quality feature.

In May 2017, the fluoride parameter showed Class I (very good) water quality characteristics at many

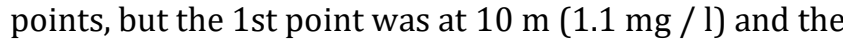

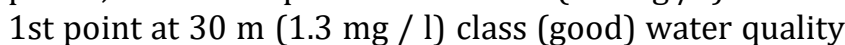
feature. In September 2016, the fluoride parameter showed class I water quality at all points. Due to the fact that the limit value of the Total Kjedahl Nitrogen (TKN) parameter is higher than the analysis results, the water quality class of the reservoir could not be evaluated in terms of this parameter. Average values of parameters measured at different periods and depths in raw water between 2016-2017 are given in Table 7.

The trophic level of the reservoir was determined by evaluating the long-term average TP, TN, chlorophyll-a and Secchi-disc depth results of the raw water. Although there is a periodic difference in terms of measured parameters, in terms of total phosphorus (mean: 44.71 $\pm 15.86 \mu \mathrm{g} / \mathrm{l}$ ) and total nitrogen (mean: $795 \pm 330 \mu \mathrm{g} / \mathrm{l}$ ), the dam lake is mesotrophic, reservoir oligotrophic in terms of chlorophyll-a (1.68 $\pm 0.90 \mu \mathrm{g} / \mathrm{l})$, mostly oligotrophic in terms of light transmittance $(4.71 \pm 2.95$ $\mathrm{m})$, mesotrophic trophic level in some periods, and dissolved oxygen concentration $(6.64 \pm 2.04 \mathrm{mg} / \mathrm{L})$. It exhibited generally mesotrophic trophic level according to SWQR trophic classification.

In addition, Carslon trophic state index values were calculated according to the long-term average total phosphorus, total nitrogen, chlorophyll-a and seki-disk depth results of the dam reservoir. Yuvacık Dam Lake shows mesotrophic characteristics with TSI (SD) $=37.67$ and TSI $(\mathrm{Chl}-\mathrm{a})=35.68$ values. It was determined eutrophic level according to the value of TSI (TP) $=58.94$. Considering all the results, it can be said that the average annual TSI value is in the 44.1 to $40-50$ band and that the dam water nutrient level is mesotrophic in this study. Total nitrogen to TP ratios have been used to indicate the limiting nutrient and the degree of nutrient limitation as noted by Smith (1982), this relationship is consistent with resource-ratio theory. Smith [23] reported that phosphorus is a limiting nutrient when the TN:TP ratio is 17 , while the TN:TP ratio is between 10-17 balanced in terms of the freshwater ecosystem. However, marine and freshwater systems have overlapping TN : TP ratios, and these ratios appear to predict equally well in both environments which of these two nutrients can become limiting for growth when nutrient concentrations are low. $\mathrm{N}$ limitation of growth, as determined by nutrient status indicators, can occur at low TN : TP ratios $(<20)$ in both freshwater and oceans. Similarly $\mathrm{P}$ limitation can occur in both environments when the TN : TP ratio is high (>50) [24]. For practical purposes, TN/TP value less than 10 indicates a nitrogen shortage, and value higher than 20 as phosphorus shortage. Lower TN/TP ratios are observed in eutrophic lakes and high in mesotrophic and oligotrophic lakes. In our study, this ratio was 19.78 per year in 2016 and 21.0 per year in 2017, and when all measurement results are taken into account, the average TN/TP value is $17.78>20$, so it can be said that nitrogen continues to be the limiting nutrient. 
Table 5. Chemical analysis results of water samples taken from different points and depths in the dam reservoir during the dry period (September 2016).

\begin{tabular}{|c|c|c|c|c|c|c|c|c|c|c|c|c|c|c|c|c|c|}
\hline \multirow[t]{2}{*}{ Parameter } & \multirow[t]{2}{*}{ Unit } & \multicolumn{16}{|c|}{ Sampling Stations } \\
\hline & & 포요 & ت્ & 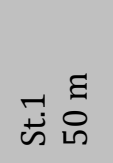 & 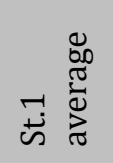 & 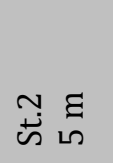 & 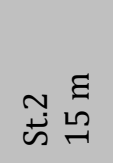 & 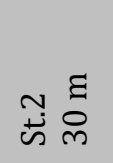 & 离 & $\begin{array}{l}m \\
\dot{\omega}\end{array}$ & $\begin{array}{l}m \\
\stackrel{\Xi}{\omega} \stackrel{1}{-1}\end{array}$ & 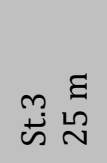 & 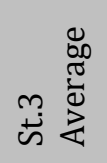 & 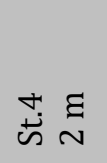 & \begin{tabular}{l}
\multirow{5}{*}{} \\
$\dot{\omega}$
\end{tabular} & 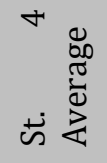 & $\begin{array}{l}\text { L } \\
\stackrel{\hbar}{\infty} \text { L }\end{array}$ \\
\hline Ammonium $\mathbf{N}$ & $\mathrm{mg} / \mathrm{L}$ & $<0,02$ & $<0,02$ & $<0,02$ & $<0,02$ & $<0,02$ & $<0,02$ & $<0,02$ & $<0,02$ & $<0,02$ & $<0,02$ & $<0,02$ & $<0,02$ & $<0,02$ & $<0,02$ & $<0,02$ & $<0,02$ \\
\hline BOD & $\mathrm{mg} / \mathrm{L}$ & 1,5 & 1,65 & 2,5 & 1,88 & 1,58 & 1,51 & 3,55 & 2,21 & 1,35 & 1,5 & 1,75 & 1,53 & 1,15 & 1,45 & 1,3 & 1,63 \\
\hline DO & $\mathrm{mg} / \mathrm{L}$ & 9,65 & 7,19 & 4,69 & 7,18 & 9,42 & 9,24 & 4,27 & 7,64 & 10,1 & 9,64 & 7,44 & 9,06 & 10,18 & 9,96 & 10,07 & 9,68 \\
\hline Fluoride & $\mathrm{mg} / \mathrm{L}$ & 0,78 & 0,42 & 0,75 & 0,65 & 0,43 & 0,91 & 0,75 & 0,70 & 0,70 & 0,20 & 0,20 & 0,37 & 0,20 & 0,60 & 0,40 & 0,17 \\
\hline Conductivity & $\mu \mathrm{S} / \mathrm{cm}$ & 226,0 & 228,0 & 236,0 & 230,0 & 243,0 & 238,0 & 247,0 & 242,6 & 231,0 & 230,0 & 251,0 & 237,3 & 232,0 & 231,0 & 231,5 & 234,0 \\
\hline COD & $\mathrm{mg} / \mathrm{L}$ & 23,6 & $<15$ & $<15$ & $<15$ & $<15$ & $<15$ & $<15$ & $<15$ & $<15$ & $<15$ & $<15$ & $<15$ & $<15$ & 20,4 & $<15$ & 24,8 \\
\hline Manganese & $\mathrm{mg} / \mathrm{L}$ & 0,003 & 0,003 & 0,005 & 0,00 & 0,003 & 0,005 & 0,005 & 0,00 & 0,004 & 0,005 & 0,03 & 0,01 & 0,005 & 0,003 & 0,004 & 0,003 \\
\hline Nitrate $\mathbf{N}$ & $\mathrm{mg} / \mathrm{L}$ & $<2$ & $<2$ & $<2$ & $<2$ & $<2$ & $<2$ & $<2$ & $<2$ & $<2$ & $<2$ & $<2$ & $<2$ & $<2$ & $<2$ & $<2$ & $<2$ \\
\hline Ortho -P & $\mathrm{mg} / \mathrm{L}$ & $\begin{array}{l}< \\
0,02\end{array}$ & $\begin{array}{l}< \\
0,02\end{array}$ & $\begin{array}{l}< \\
0,02\end{array}$ & $\begin{array}{l}< \\
0,02\end{array}$ & $\begin{array}{l}< \\
0,02\end{array}$ & $\begin{array}{l}< \\
0,02\end{array}$ & $\begin{array}{l}< \\
0,02\end{array}$ & $\begin{array}{l}< \\
0,02\end{array}$ & $\begin{array}{l}< \\
0,02\end{array}$ & $\begin{array}{l}< \\
0,02\end{array}$ & $\begin{array}{l}< \\
0,02\end{array}$ & $\begin{array}{l}< \\
0,02\end{array}$ & $\begin{array}{l}< \\
0,02\end{array}$ & $\begin{array}{l}< \\
0,02\end{array}$ & $\begin{array}{l}< \\
0,02\end{array}$ & $<0,02$ \\
\hline pH & - & 7,82 & 7,16 & 7,06 & 7,35 & 7,88 & 7,81 & 7,17 & 7,62 & 8,09 & 7,85 & 7,56 & 7,83 & 8,03 & 8,02 & 8,025 & 8,07 \\
\hline Selenium & $\mathrm{mg} / \mathrm{L}$ & $\begin{array}{l}< \\
0,01\end{array}$ & $\begin{array}{l}< \\
0,01\end{array}$ & $\begin{array}{l}< \\
0,01\end{array}$ & $\begin{array}{l}< \\
0,01\end{array}$ & $\begin{array}{l}< \\
0,01\end{array}$ & $\begin{array}{l}< \\
0,01\end{array}$ & $\begin{array}{l}< \\
0,01\end{array}$ & $\begin{array}{l}< \\
0,01\end{array}$ & $\begin{array}{l}< \\
0,01\end{array}$ & $\begin{array}{l}< \\
0,01\end{array}$ & $\begin{array}{l}< \\
0,01\end{array}$ & $\begin{array}{l}< \\
0,01\end{array}$ & $\begin{array}{l}< \\
0,01\end{array}$ & $\begin{array}{l}< \\
0,01\end{array}$ & $\begin{array}{l}< \\
0,01\end{array}$ & $<0,01$ \\
\hline Temperature & ${ }^{\circ} \mathrm{C}$ & 20,4 & 10,1 & 9,1 & 13,20 & 20,9 & 20,1 & 11,4 & 17,47 & 21,6 & 16,7 & 14,2 & 17,5 & 21,5 & 16,9 & 19,2 & 18,3 \\
\hline TKN & $\mathrm{mg} / \mathrm{L}$ & $<1$ & $<1$ & $<1$ & $<1$ & $<1$ & $<1$ & $<1$ & $<1$ & $<1$ & $<1$ & $<1$ & $<1$ & $<1$ & $<1$ & $<1$ & $<1$ \\
\hline
\end{tabular}


Table 6. Chemical analysis results of water samples taken from different points and depths in the dam reservoir during the wet period (May 2017).

\begin{tabular}{|c|c|c|c|c|c|c|c|c|c|c|c|c|c|c|c|c|c|}
\hline \multirow[t]{2}{*}{ Parameter } & \multirow[t]{2}{*}{ Unit } & \multicolumn{16}{|c|}{ Sampling Stations } \\
\hline & & 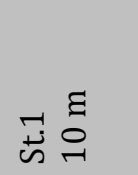 & 芜 & 퐁 & 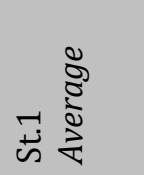 & 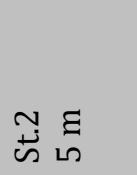 & N & N & 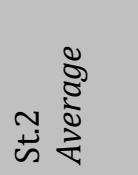 & $\stackrel{m}{\infty}$ & m & $\underset{m}{m} \stackrel{\Xi}{\sim}$ & 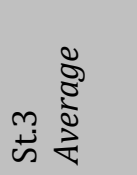 & $\begin{array}{l}\stackrel{t}{*} \approx \\
\stackrel{\sim}{N}\end{array}$ & $\begin{array}{l}\sigma \\
\stackrel{+}{\infty} \Xi\end{array}$ & 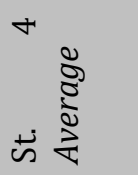 & 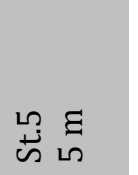 \\
\hline $\begin{array}{l}\text { Ammonium } \\
\mathrm{N}\end{array}$ & $\mathrm{mg} / \mathrm{L}$ & $<0,02$ & $<0,02$ & $<0,02$ & $<0,02$ & $<0,02$ & $<0,02$ & $<0,02$ & $<0,02$ & $<0,02$ & $<0,02$ & $<0,02$ & $<0,02$ & $<0,02$ & $<0,02$ & $<0,02$ & $<0,02$ \\
\hline BOD & $\mathrm{mg} / \mathrm{L}$ & 1,58 & 1,95 & 2,50 & 2,01 & 2,58 & 1,51 & 2,55 & 2,21 & 1,35 & 1,95 & 1,73 & 1,68 & 1,25 & 1,49 & 1,37 & 1,43 \\
\hline DO & $\mathrm{mg} / \mathrm{L}$ & 7,96 & 8,52 & 10,20 & 8,89 & 8,78 & 9,64 & 10,83 & 9,75 & 7,34 & 8,39 & 10,56 & 8,76 & 10,75 & 10,40 & 10,58 & 11,31 \\
\hline Fluoride & $\mathrm{mg} / \mathrm{L}$ & 1,10 & 1,30 & 0,90 & 1,10 & 0,90 & 0,92 & 0,78 & 0,87 & 0,75 & 0,68 & 0,84 & 0,76 & 0,52 & 0,40 & 0,46 & 0,42 \\
\hline Conductivity & $\mu \mathrm{S} / \mathrm{cm}$ & 235,00 & 235,00 & 236,00 & 235,33 & 238,00 & 244,00 & 238,00 & 240,00 & 235,00 & 241,00 & 229,00 & 235,00 & 223,00 & 239,00 & 231,00 & 216,00 \\
\hline COD & $\mathrm{mg} / \mathrm{L}$ & 20,50 & $<15$ & $<15$ & $<15$ & $<15$ & $<15$ & $<15$ & $<15$ & $<15$ & $<15$ & $<15$ & $<15$ & $<15$ & $<15$ & $<15$ & $<15$ \\
\hline Manganese & $\mathrm{mg} / \mathrm{L}$ & 0,03 & 0,01 & 0,01 & 0,02 & 0,01 & 0,01 & 0,01 & 0,01 & 0,02 & 0,01 & 0,01 & 0,01 & 0,01 & 0,01 & 0,01 & 0,02 \\
\hline Nitrate $\mathbf{N}$ & ${ }_{/ \mathrm{Lg}}^{\mathrm{mg}}$ & $<2$ & $<2$ & $<2$ & $<2$ & $<2$ & $<2$ & $<2$ & $<2$ & $<2$ & $<2$ & $<2$ & $<2$ & $<2$ & $<2$ & $<2$ & $<2$ \\
\hline Ortho -P & $\mathrm{mg} / \mathrm{L}$ & $<0,02$ & $<0,02$ & $<0,02$ & $<0,02$ & $<0,02$ & $<0,02$ & $<0,02$ & $<0,02$ & $<0,02$ & $<0,02$ & $<0,02$ & $<0,02$ & $<0,02$ & $<0,02$ & $<0,02$ & $<0,02$ \\
\hline pH & - & 7,95 & 7,84 & 8,51 & 8,10 & 8,01 & 8,28 & 7,76 & 8,02 & 7,48 & 7,94 & 8,44 & 7,95 & 8,50 & 7,80 & 8,15 & 8,50 \\
\hline Selenium & $\mathrm{mg} / \mathrm{L}$ & $<0,01$ & $<0,01$ & $<0,01$ & $<0,01$ & $<0,01$ & $<0,01$ & $<0,01$ & $<0,01$ & $<0,01$ & 0,01 & $<0,01$ & $<0,01$ & 0,01 & 0,01 & 0,01 & 0,01 \\
\hline Temperature & ${ }^{\circ} \mathrm{C}$ & 12,00 & 9,10 & 14,20 & 11,77 & 11,90 & 13,40 & 15,80 & 13,70 & 10,50 & 12,50 & 17,90 & 13,63 & 17,70 & 15,80 & 16,75 & 17,80 \\
\hline TKN & $\mathrm{mg} / \mathrm{L}$ & $<1$ & $<1$ & $<1$ & $<1$ & $<1$ & $<1$ & $<1$ & $<1$ & $<1$ & $<1$ & $<1$ & $<1$ & $<1$ & $<1$ & $<1$ & $<1$ \\
\hline
\end{tabular}


Table 7. Time-dependent variation of the average value of the measured parameters in the water column in the reservoir raw water between 2016 and 2017.

\begin{tabular}{|c|c|c|c|c|c|}
\hline Sampling Time & Toplam P $(\mu \mathrm{g} / \mathrm{L})$ & Toplam N $(\mu \mathrm{g} / \mathrm{L})$ & Chlorophyll-a $(\mu \mathrm{g} / \mathrm{L})$ & $\begin{array}{c}\text { Secchi Disc Derinliği } \\
(\mathrm{m})\end{array}$ & Dissolved Oxygen (mg/L) \\
\hline January 16 & 30 & 1300 & 1,3 & 3,1 & 4,7 \\
\hline Feb 16 & 40 & 500 & 2,1 & 6 & 7,5 \\
\hline March 16 & 50 & 300 & 2,5 & 2,7 & 8,7 \\
\hline April 16 & - & 600 & 1,6 & 9,8 & 6,9 \\
\hline May 16 & 40 & 500 & 2,4 & 9,3 & 5,1 \\
\hline June 16 & 30 & 1100 & 2,1 & 9,0 & 3,0 \\
\hline July 16 & 30 & 900 & 4,3 & - & 4,4 \\
\hline August 16 & 30 & 1000 & 1,8 & 8,7 & 5,5 \\
\hline September 16 & 30 & 1000 & 1,8 & 6,0 & 8,5 \\
\hline October 16 & 80 & 800 & 0,5 & 5,4 & 4,9 \\
\hline November 16 & 60 & 800 & 0,5 & - & 4,2 \\
\hline December 16 & 40 & 300 & 0,7 & 4,8 & 7,6 \\
\hline January 17 & 50 & 700 & - & 1,2 & 8,6 \\
\hline Feb 17 & 80 & 1500 & - & 1,1 & 7,4 \\
\hline March 17 & 50 & 1000 & - & 1,7 & 7,6 \\
\hline April 17 & 40 & 700 & 1,0 & 1,2 & 3,5 \\
\hline May 17 & 40 & 1200 & 1,8 & 2,9 & 9,6 \\
\hline June 17 & 40 & 700 & 1,7 & 2,3 & 9,4 \\
\hline July 17 & - & - & 1,3 & 5,1 & 8,5 \\
\hline August 17 & - & 500 & 1,9 & 4,4 & 7,2 \\
\hline Average & 44,71 & 795,00 & 1,68 & 4,71 & 6,64 \\
\hline Standard deviation & 15,86 & 329,81 & 0,90 & 2,95 & 2,04 \\
\hline Minimum & 30 & 300 & 0,50 & 1,10 & 3,00 \\
\hline Maximum & 80 & 1500 & 4,30 & 9,80 & 9,55 \\
\hline
\end{tabular}

\section{Results and Recommendations}

With this study, in which the seasonal characteristics of the Yuvacik drinking water reservoir in Kocaeli province were determined, raw water samples were taken from the points determined in the Yuvacık dam lake, which meets approximately $90 \%$ of the water need of Kocaeli province, for two periods. Raw water characterization and quality category were made by evaluating the analysis results of water samples. In addition, the trophic level of the dam reservoir has been determined. The results and evaluations obtained as a result of the studies are given below.

- Considering the Quality Criteria of Inland Surface Water Resources According to their Classes in terms of General Chemical and Physicochemical Parameters, Yuvacik Dam raw water, which is the subject of this study, has many parameters $(\mathrm{pH}, \mathrm{EC}$, chemical oxygen demand, biological oxygen demand, ammonium nitrogen, nitrate) for the samples taken from the surface. nitrogen, ortho phosphate phosphorus, manganese and selenium parameters) shows Class I (very good) water quality characteristics. Although there are periodic variations in some parameter values measured in the dam surface water, this does not significantly affect the quality of the water. Reservoir water is generally an alkaline $\mathrm{pH}$; The values were measured in the aqueous period (eg $\mathrm{pH}$ : $8.1 \pm 0.3$ in May) and in the dry period, for example in September (pH: $7.7 \pm 0.4)$.

- The EC value of the reservoir water is also moderate, with no significant seasonal variation (Average EC, May: $234 \pm 7.9 \mu \mathrm{S} / \mathrm{cm}$, September: $236 \pm 7.8 \mu \mathrm{S} / \mathrm{cm}$ ). It is seen that the EC value of the reservoir water is similar to the EC values of the spring water.

- The average temperature of the reservoir raw water in September $\left(16.76 \pm 4.55^{\circ} \mathrm{C}\right)$ was higher than in May $\left(9.8 \pm 2.97^{\circ} \mathrm{C}\right)$. It was observed that the temperature increased with the increase in depth in September, and there was no significant change in temperatures depending on the depth in May.

- Average dissolved oxygen saturation of the reservoir raw water in September $(84 \pm 23 \%)$ was higher than in May $(96 \pm 13 \%)$. It is observed that the dissolved oxygen concentration is higher in the May period due to the lower water temperatures in May compared to September. The lowest DO saturation was measured at $30 \mathrm{~m}$ depth $(42.7 \%)$ at the midpoint of the dam reservoir (station No 2) and at a depth of $50 \mathrm{~m} \mathrm{(46.9 \% )}$ near the intake structure (station No 1). The differentiation observed in basic water parameters depending on depth in September period is not observed in May period. DO saturation measured at the deepest points of the reservoir in May was $102 \%$ at the 1 st station ( $50 \mathrm{~m}), 108 \%$ at the $2 \mathrm{nd}$ station $(21 \mathrm{~m})$, and $106 \%$ at the $3 r d$ station $(25 \mathrm{~m})$. All these data show that the water column in the reservoir was mixed well in the May period. The stratification caused by the temperature difference in the reservoir in September is thought to cause differences in water parameters.

- In September 2016, the dissolved oxygen parameter showed Class I (very good) water quality characteristics at many points, but the deep measurement results at the measurement stations 1 and 2 showed that the oxygen levels decreased compared to the results at other points. Therefore, in terms of dissolved oxygen in the lake under the effect of the autumn mixture, II. class (good) water quality feature. In May 2017, the surface water showed Class I (very good) water quality characteristics in many points in terms of dissolved oxygen parameter, but again, with an average value of $8.89 \mathrm{mg} / \mathrm{L}$ at station 1 and $8.76 \mathrm{mg} / \mathrm{l}$ at Point 3. class (good) water quality feature. 
- In May 2017, while the fluoride parameter showed Class I (very good) water quality characteristics at many points, again at the station number 1 , an average of $1.1 \mathrm{mg} / \mathrm{L}$ was achieved. class (good) water quality feature. In September 2016, it was determined that the surface water in terms of the fluoride parameter was of class I water quality at all points.

- According to the analysis results, the water quality class of the reservoir could not be evaluated in terms of these parameters due to the high limit value of TKN detection. Maraşlıoğlu and Gönülol (2014) stated in a study on the trophic structure of the Yedikır Dam Lake that some indices such as TSI are weak indicators of the real trophic status of the area [25]. Although there are variations in the nutrient level of the reservoir according to the measured parameters, in terms of TP (mean: $44.71 \pm 15.86 \mu \mathrm{g} / \mathrm{l}$ ), the trophic level of the dam surface water is mesotrophic according to SWQR while it is eutrophic according to Carlson classification. Also, it exhibited mostly oligotrophic levels in terms of Chl-a (mean: $1.68 \pm 0,90 \mu \mathrm{g} / \mathrm{l}$ ) and light transmittance (mean Secchi depht: $4.71 \pm 2.95 \mathrm{~m}$ ). In this respect, it can be said that the trophic level of the reservoir preserves its mesotrophic character according to both of classification critera.

- The reservoir has shown Class I (very good) water quality at many points, but at some depths II. It showed class (good) water quality feature. Considering within the scope of the regulation, since the higher class of water quality parameters is valid, the reservoir waters sampled throughout this study are generally considered to be II. Class (good) water quality feature has been determined.

In order to ensure the sustainable management of water resources; It is important to monitor the water quality on a yearly basis, to determine the sources of pollution and to take appropriate measures.

\section{Acknowledgements}

The authors would like to thank Nevşehir Hacı Bektaş Veli University Scientific Research Projects (BAP) Coordinator for their support to the project numbered YLTPF13. This article has been produced from the master's thesis named "Investigation of Drinking Water Spring Water in Kocaeli Province".

\section{References}

[1] Karadavut, İ.S., Saydam, A.C., Kalıpcl, E., Karadavut, S., Özdemir, C., "A research for water pollution of Melendiz stream in terms of sustainability of ecological balance”. Carpt. J. Earth Environ. Sci., 6(1):65-80, 2011.

[2] Gündoğdu, V., Kocataş, A., "Gediz nehir havzası yönetim planı oluşturulmasına yönelik bir yaklaşım", E.Ü. Su Ürün.Der., 23(3-4):371-378, 2006.

[3] Kalıpcl, E.. "Spatial Analysis Of Water Pollution by Geography Information Sytems (GIS) in Turkey", 4nd Inte. Confer. on Material Sci. and Tech. in Kizılcahamam (IMSTEC'19,. Ankara/ TURKEY: Nevşehir Hacı Bektaş Veli Uni., 2019 October, p.806.
[4] Durga Rao, K.H.V.,"Multi-criteria spatial decision analysis for forecasting urban water requirements: a case study of dehradun city", India, Lands. and Urban Plan., 71:163-174, 2005.

[5] Kalıpcı, E., Cüce, H., Toprak, S., "Damsa Barajı (Nevşehir) yüzey suyu kalitesinin coğrafi bilgi sistemi ile mekansal analizi", Karaelmas Sci. and Engin. J., 7(1):312-319,2017.

[6] Cüce, H. Kalıpcı, E., Taş, B., Yılmaz, M., "Rakım farklılığı nedeniyle oluşan meteorolojik değişimlerin su kalitesine olan etkilerinin CBS ile değerlendirilmesi: morfolojik olarak farklı iki göl için bir karşılaştırma", Karadeniz Fen Bilim. Derg. 10(1):126,2020 .

[7] Ustaoğlu, F., Tepe, Y., "Water quality and sediment contamination assessment of Pazarsuyu Stream, Turkey using multivariate statistical methods and pollution indicators", International Soil and Water Conservation Research, 7(1):47-56,2019.

[8] Ustaoğlu, F., Tepe, Y., Taş B., “Assessment of stream quality and health risk in a subtropical Turkey river system: a combined approach using statistical analysis and water quality index", Ecological Indicators, https ://doi.org/10.1016/j.ecoli nd.2019.105815, 2020.

[9] Kalıpcl, E., Cüce, H., Toprak, S., “Coğrafi bilgi sistemleri (CBS) kullanılarak Mamasın barajı yüzey suyu kalitesinin değerlendirilmesi", Ömer Halisdemir Üni. Mühendislik Bilim. Derg., 6(2):351-361, 2017.

[10] Anonim, Kocaeli Büyükşehir Belediyesi İzmit Su A.Ş., "İzmit Su Temin Projesi", İSAŞ 01, s. 9-10, Kocaeli, 1999.

[11] Zengin, M., Hızal, A., Karakaş, A., Serengil, Y., Tuğrul, D., Ercan, M., "İzmit Yuvacık barajı su toplama havzasının yenilenebilir doğal kaynaklarının su üretimi (kalite, miktar ve rejim) amacıyla planlanması", Çevre ve Orman Bakan. Teknik Bült., Kocaeli, 197: 2-40,2005.

[12] Anonim, Kocaeli Büyükșehir Belediyesi İzmit Su Kanalizasyon İdaresi, İSU, 12, Kocaeli, s. 28, 2015.

[13] Anonim, Cemre Mühendislik Lab. İnş. San. ve Tic. Ltd. Ști., "Yuvacık Barajı Havzası'nın Özel Hüküm Belirlemesine Esas Jeolojik ve Hidrojeolojik Etütü", Cemre Mühendislik 01, Kocaeli, s. 24-42, 2015.

[14] Carlson, R.E., "A trophictate Index for lakes". Limnology and Oceanography, (22):361-369, 1977.

[15] Dodds W. K., Jones J. R., Welch E. B., "Suggested classification of stream trophic state: distributions of temperate stream types by chlorophyll, total nitrogen, and phosphorus", Water Res. 32: 1455-1462, 1998.

[16] Bajkiewicz-Grabowska E., "Trophic diversity of lakes - present state, the place in trophic classification [in:] Borowiak D. (ed.), Lakes of the Kashubian Landscape Park", KLUG, Gdańsk: 293-305, 2007.

[17] Jeppesen E, Peder Jensen J, SØndergaard M, Lauridsen T, Landkildehus F., "Trophic structure, species richness and biodiversity in Danish lakes: changes along a phosphorus gradient". Freshwater biology. 45(2):201-218, 2000. 
[18] Şengül, F., Müezzinoğlu, A. “Çevre Kimyası” D.E.Ü. Çevre Müh. Böl. Basım Ünitesi, İzmir, 2008.

[19] Özdemir, N., Yllmaz, F., Yorulmaz, B., "Dalaman çayı üzerindeki bereket hidro elektrik santrali baraj gölü suyunun bazı fiziko-kimyasal parametrelerinin ve balık faunasının araştırılması, Ekoloji, 16(62):30-36, 2007.

[20] Ünlü A., Çoban F., Tunç M.S.,"Hazar gölü su kalitesinin zamanla değişimi”, Gazi Üni. Müh. Mim. Fak. Dergisi, 23(1):119-127, 2008.

[21] Hasanoğlu, E., “Borabey göletinin termal katmanlașma yapısının ve çözünmüș oksijen profilinin incelenmesi ve CE-QUAL-W2 ile modellenmesi". Yüksek Lisans Tezi, Anadolu Üni., Fen Bil. Enst., Eskişehir, 2015.
[22] Göncül, S., Hasanoğlu, E., Avdan, U., Avdan, Z., Albek, A., "Borabey göleti'nin termal katmanlaşma yapısının incelenmesi”, Anadolu Üni. Bilim ve Tekno. Derg. A-Uyg.Bil. ve Müh.,16(3):351-366, 2015.

[23] Smith, V., "The nitrogen and phosphorus dependence of algal biomass in lakes: an empirical and theoretical analysis. Limnol. Oceanogr. 27:1101-12, 1982.

[24] Guildford S.J., Hecky R.E., “Total nitrogen, total phosphorus, and nutrient limitation in lakes and oceans: Is there a common relationship?" Limnol. Oceanogr., 45(6), 1213-1223, 2000.

[25] Maraşlığlu, F., Gönülol A., "Phytoplankton Community, Functional Classification and Trophic State Indices of Yedikır Dam Lake (Amasya)", J. Biol. Environ. Sci.,8(24):133-141,2014. 